Original research article

\title{
Determinants of quality life of patients with psoriasis treated with biologics
}

\author{
Slávka Mrosková ${ }^{*}$, Viera Konečná ${ }^{2}$, Gabriela Kuriplachová ${ }^{1}$, Elena Gurková ${ }^{3}$ \\ ${ }^{1}$ University of Prešov, Faculty of Health Care, Department of Nursing, Prešov, Slovak Republic \\ 2 Faculty Hospital J. A. Reiman in Prešov, Department of Dermatovenerology, Prešov, Slovak Republic \\ ${ }^{3}$ Palacký University, Faculty of Health Sciences, Department of Nursing, Olomouc, Czech Republic
}

\begin{abstract}
Aim: The aim of the study was to assess the quality life of patients with psoriasis treated with biologics, and to analyze the various factors that determine it.

Methods: The cross-sectional study was realized with 117 patients at the Centre for Biologic Therapy in Slovakia. The factors analyzed were: Dermatology Life Quality Index (DLQI), The Brief Illness Perception Questionnaire (BIPQ), General Anxiety Disorder-7 (GAD-7), Psoriasis Area Severity Index (PASI), localization of skin changes, duration of the disease, length of use of biologics, BMI.

Results: Mean score of DLQI was 9.03 (SD = 6.59, range $=2-23$ ). DLQI significantly correlates with PASI $(r=0.347)$, length of use of biologics $(r=-0.286)$, illness perception $(r=0.557)$ and anxiety $(r=0.338)$. Hierarchical regression analysis showed that PASI $(\beta=0.252)$ and illness perception $(\beta=2.209)$ were significant predictors of a patient's quality life.

Conclusions: The findings of study indicate that the quality life of psoriatic patients treated with biologics is determined by the disease severity and illness perception. Therefore it is very important to include a psychosocial dimension (assessment, effective intervention) in the care of these patients.
\end{abstract}

Keywords: Anxiety; Disease severity; Illness perception; Psoriasis vulgaris; Quality of life

Abbreviations: BIPQ - The Brief Illness Perception Questionnaire; BMI - Body Mass Index; DLQI - Dermatology Life Quality Index; GAD-7 - General Anxiety Disorder-7; HAD - Hospital Anxiety and Depression scale; HRQOL - Health-Related Quality of Life; PASI - Psoriasis Area and Severity Index

\section{Introduction}

Psoriasis vulgaris is a genetic and chronic inflammatory systemic skin disease (Higgins, 2017). The prevalence of this disease varies widely from 0.51 to $11 \%$ (WHO, 2016) in relation to demographic characteristics and geographic region (Parisi et al., 2013). The therapy of psoriasis integrates topical, systematic and biologic treatment (Higgins, 2017). Biologic treatment is designed for patients with moderate to severe psoriasis (PASI $\geq 10$ and DLQI 210) (Calara et al., 2016), if systematic therapy fails or is contraindicated (Menting et al., 2014). Several systematic reviews have demonstrated the negative effect of psoriasis on the health-related quality of life (HRQOL) and the positive effect of biological treatment on the HRQOL compared to systemic or topical treatment (Norris et al., 2017; Obradors et al., 2016; Takahashi et al., 2014).

Psoriasis vulgaris has a pronounced psychosocial dimension. It is associated with anxiety and depression, mood disorders, substance dependence or abuse (Ferreira et al., 2016), and problems with sleep (Kaaz et al., 2019). Anxiety and depression have been analyzed by several authors (Mattei et al.,
2014; Takahashi et al., 2014; Wu et al., 2016). In a review article by Fleming et al. (2017), the prevalence of anxiety in patients with psoriasis was between $7-48 \%$.

The perception of the disease describes mental representations and personal thoughts of people about their illness (Broadbent et al., 2015). This is understood as a significant phenomenon determining patient behavior (Hagger and Orbell, 2003), treatment adherence and coping mechanisms (Zhang et al., 2016), thereby changing the course and results of the disease. Research on illness cognition or health-related beliefs has been stimulated by a theoretical framework by Leventhal et al. (1992). Illness perception integrated areas such as timeline, causal factors, treatment control, emotional representation, and illness concern (Broadbent et al., 2006). Beliefs about illness are an important factor for quality of life in many chronic diseases (Kotsis et al., 2014; Zhang et al., 2016), and also in patients with psoriasis (Kotsis et al., 2012; Salemi et al., 2016; Wahl et al., 2014). In a meta-analytic review integrating 45 studies, only 3 studies examined illness perception in patients with Psoriasis vulgaris (Hagger and Orbell, 2003). Perception of the disease represents a potential determinant affecting the quality of life, but this is not sufficiently analyzed in psoriasis patients.

\footnotetext{
* Corresponding author: Slávka Mrosková, University of Prešov, Faculty of Health Care, Department of Nursing, Partizánska 1, 08001 Prešov, Slovak Republic, e-mail: slavka.mroskova@unipo.sk http://doi.org/10.32725/kont.2020.039 
The main objective of the research was to analyze factors influencing HRQOL, including illness perception and anxiety, in patients with Psoriasis vulgaris in biological therapy.

\section{Materials and methods}

\section{Participants and recruitment}

Data collection was carried out at the Faculty Hospital of J. A. Reiman in Prešov in the Centre for Biological Treatment. The research was conducted with the consent of the hospital ethics committee (protocol number: 48/EK/2017). The distribution of the questionnaires and their completion by respondents was carried out during the patient's visit in the centre. Nurses instructed patients about the aim, focus of the questionnaire and how to fill it out. In total 160 respondents were approached to cooperate in the research project. We excluded 43 respondents from the analysis (incomplete data in the questionnaire). The research group consisted of 117 respondents.

\section{Instruments}

Dermatology Life Quality Index (DLQI) (Finlay and Khan, 1994) is one of the most commonly used tools in HRQOL in patients with skin problems (Ali et al., 2017). Total score is 0-30. A higher score means worse HRQOL. The Cronbach alpha in this study was 0.925 .

The Brief Illness Perception Questionnaire (BIPQ) (Broadbent et al., 2006) is a tool for analyzing the patient's perception of the disease. Each of the eight items evaluates a separate area (Table 2). The mean scores for these items range from 0 to 10. Higher scores reflect worse perceptions, i.e. worse patient views of their disease. The Cronbach alpha in this study was 0.597 .

General Anxiety Disorder-7 (GAD-7) (Spitzer et al., 2006) is a useful screening tool for anxiety in psoriatic patients (Higgins, 2017). Possible range from 0 to 21. The Cronbach alpha in this study was 0.895 .

Health record data: the duration of the disease, the duration of biological treatment, BMI, PASI, localization of skin changes. Psoriasis Severity Index (PASI) evaluates the severity of skin changes. The PASI value ranges from 0 (no disease or disease without apparent skin changes) to 72 (maximum) (Reich and Griffiths, 2008). A higher value means greater severity of skin disease manifestations.

\section{Sample}

The average age of respondents was 51 years, male sex dominated slightly (59.8\%). The average duration of the disease (length of use of biologics) was 19 years (4.5 years). The average PASI found was $3.00 ; 34.2 \%$ of respondents were overweight and $33.3 \%$ were grade 1 obese (Table 1 ).

\section{Statistical analysis}

First, we considered the normal distribution of variables. Data is described using the mean $(M)$, standard deviation $( \pm S D)$, or percent (\%). We used an independent t-test or ANOVA test to analyze mean differences. Pearson correlation was used for analysing the association between two continuous variables. The testing of the influence of selected independent variables on the quality of life (dependent variable) was performed by multi regression linear analysis. The hierarchical regression was as follows: in the first model we included demographic variables, in the second model disease factors, in the third model psychological factors. SPSS 19.00 software was used in the statistical analysis. Statistical significance was at $p<0.05$.
Table 1. Demographics and clinical characteristics of the study respondents $(n=117)$

\begin{tabular}{|c|c|}
\hline \multicolumn{2}{|l|}{ Parameters } \\
\hline Age (years) & \\
\hline $\mathrm{M}(\mathrm{SD})$, range & 51.61 (11.86), 23-82 \\
\hline \multicolumn{2}{|l|}{$\operatorname{Sex} n(\%)$} \\
\hline male & $70(59.8)$ \\
\hline female & $47(40.2)$ \\
\hline \multicolumn{2}{|l|}{ Residence $n(\%)$} \\
\hline city & $51(43.6)$ \\
\hline village & $66(56.4)$ \\
\hline \multicolumn{2}{|c|}{ Duration of disease (years) } \\
\hline M (SD), range & $19.64(12.12)$, range $=1-57$ \\
\hline \multicolumn{2}{|c|}{ Length of use of biologics (years) } \\
\hline $\mathrm{M}$ (SD), range & $4.49(2.39)$, range $=0.1-11$ \\
\hline \multicolumn{2}{|l|}{ PASI } \\
\hline M (SD), range & $3.00(5.08)$, range $=0-35$ \\
\hline \multicolumn{2}{|c|}{$\begin{array}{l}\text { Skin changes in visible places (face, hair, } \\
\text { hand, nails, generalized form) } \\
n(\%)\end{array}$} \\
\hline yes & $48(41.0)$ \\
\hline no & $69(59.0)$ \\
\hline \multicolumn{2}{|l|}{ BMI n (\%) } \\
\hline $18.5-25$ & $22(18.8)$ \\
\hline $25-30$ & $40(34.2)$ \\
\hline $30-35$ & $39(33.3)$ \\
\hline $35-40$ & $13(11.1)$ \\
\hline$>40$ & $3(2.6)$ \\
\hline
\end{tabular}

\section{Results}

\section{Quality of life, anxiety and illness perception}

The mean of DLQI was 9.03 (SD = 6.59, range $=2-23$ ), so the patient's quality of life is changed slightly. In $41.0 \%$ of patients we found a small effect of psoriasis on HRQOL,in $24.8 \%$ a moderate effect, and in $25.6 \%$ of patients we found a very large effect (Table 2).

The mean score of anxiety was 6.65 (SD = 4.86). A mild level of anxiety was found in $37.6 \%$ of the respondents and $35.9 \%$ had negative anxiety screen (Table 2 ).

The mean score of BIPQ was 4.60 (SD = 1.35). High average values, and thus poor perception, were found mainly in the following domains: timeline score $(\mathrm{M}=9.26)$ and the consequences of the disease score $(\mathrm{M}=7.04)$. On the contrary, areas with a good perception were treatment control $(\mathrm{M}=1.17)$ and disease coherence $(\mathrm{M}=1.31)$ (Table 2).

\section{Quality of life and socio-demographic factors/clinical characteristics/anxiety/illness perception}

We did not find any significant differences in the quality of life with regards to sex $(p=0.222)$ and residence $(p=0.927)$. The quality of life in respondents $<40$ years of age was 9.68 $(\mathrm{SD}=6.27)$, at $41-60$ years was $9.24(\mathrm{SD}=6.69)$, and at age $>60$ years $7.96(\mathrm{SD}=6.67)(p=0.629)$.

The analysis of average values of quality of life in individual BMI categories (BMI $<25 \mathrm{~kg} / \mathrm{m}^{2}=6.64 \pm 4.96$; BMI $25-30 \mathrm{~kg} /$ $\left.\mathrm{m}^{2}=9.08 \pm 7.29 ; \mathrm{BMI}>30 \mathrm{~kg} / \mathrm{m}^{2}=9.95 \pm 6.50\right)$ indicates a decrease in quality of life with increasing BMI, but the differences between groups are not significant $(p=0.138)$. 
Table 2. Descriptive data about HRQOL (DLQI), anxiety (GAD-7) and illness perception (BIPQ)

\begin{tabular}{lc} 
DLQI score & $n(\%)$ \\
no effect $(0-1)$ & $0(0.0)$ \\
small effect $(2-5)$ & $48(41.0)$ \\
moderate effect $(6-10)$ & $29(24.8)$ \\
very large effect $(11-20)$ & $30(25.6)$ \\
extremely large effect $(21-30)$ & $10(8.5)$ \\
\hline GAD-7 & $n(\%$ \\
negative anxiety screen $(<4)$ & $42(35.9)$ \\
mild level of anxiety (5-9) & $44(37.6)$ \\
moderate level of anxiety $(10-14)$ & $22(18.8)$ \\
severe level of anxiety $(>15)$ & $9(7.7)$ \\
\hline Domain BIPQ & $\mathrm{M}(\mathrm{SD})$ \\
consequences score & $7.04(2.87)$ \\
timeline score & $9.26(1.83)$ \\
personal control score & $2.62(2.67)$ \\
treatment control score & $1.17(1.92)$ \\
identity score & $6.23(2.88)$ \\
illness concern & $6.87(2.93)$ \\
emotional representation score & $5.76(2.98)$ \\
coherence score & $1.31(2.01)$ \\
\hline M - mean; SD - standard deviation. & \\
\hline
\end{tabular}

M - mean; SD - standard deviation.

Patients with skin lesions located in visible areas and generalized psoriasis had significantly worse quality of life $(10.94 \pm 6.32)$ than patients with psoriatic focus in less visible areas (crus, back) $(7.70 \pm 6.49)(p=0.008)$.

DLQI significantly correlates with the severity of skin changes (PASI) $(r=0.347)$, with the duration of biological treatment $(r=-0.286)$, illness perception $(r=0.557)$, as well as anxiety $(r=0.338)$ (Table 3$)$. So higher level of anxiety, poor perception of the disease by the patient, and severe skin changes worsen the quality of life, whereas longer treatment with biologics improves the quality of life.

At the same time, we found an association between the duration of biological therapy and PASI $(r=-0.244, p=0.015)$.

In the subsequent multi regression analysis, model 1 analyzed demographic factors (age, sex) where no significance was found. In Model 2, disease-related factors (disease duration, duration of biological treatment, PASI, BMI) were integrated into regression. Quality of life was determined by PASI ( $p=$ $0.000)$ and BMI $(p=0.018)$. Demographic factors and disease
Table 3. Pearson correlation between quality of life and socio-demographic factors/clinical characteristics/illness perception/anxiety

\begin{tabular}{lc} 
& DLQI \\
\hline Age & -0.129 \\
Duration of the disease & -0.061 \\
Length of use of biologics & $-0.286^{* *}$ \\
PASI & $0.347^{* *}$ \\
BIPQ score & $0.557^{* *}$ \\
GAD-7 & $0.338^{* *}$ \\
\hline
\end{tabular}

** Correlation significant at level 0.01 (2-tailed)

factors explain $15 \%$ of the variation of the quality of life. In model 3, psychological factors (anxiety, illness perception) were integrated into the analysis. Significant factors in this model are: PASI $(\beta=0.252, p=0.021)$ and illness perception $(\beta=2.209, p=0.000)$. All the factors analyzed explain $34 \%$ of the variation of the patient's quality of life $(p=0.000)$ (Table 4).

\section{Discussion}

This research analyzed the quality of life and identifying determining factors in patients with Psoriasis vulgaris in biological therapy. The overall DLQI score indicates that the quality of life of patients is slightly affected. Nearly half of the respondents noticed little impact on the quality of life (DLQI 2/5). These findings are related to the type of treatment (biologics) and severity of skin changes (low PASI). On the one hand, we have shown an association between the quality of life and the duration of biological therapy, and the quality of life and severity of skin changes (PASI). On the other hand, we found an association between the duration of biological treatment and PASI. The aim of the psoriatic therapy is to achieve 75\% PASI (Mattei et al., 2014). Any decrease in PASI, even minimal, is desirable because it leads to an improvement in the quality of life. The biological treatment can significantly improve skin appearance in patients with psoriasis, and thus has a positive impact on their quality of life (Mattei et al., 2014; Puig et al., 2017).

Table 4. Hierarchical model of the factors associated with DLQI

\begin{tabular}{|c|c|c|c|c|c|c|}
\hline & \multicolumn{2}{|c|}{ Model 1} & \multicolumn{2}{|c|}{ Model 2} & \multicolumn{2}{|c|}{ Model 3} \\
\hline & $\beta$ & sig. & $\beta$ & sig. & $\beta$ & sig. \\
\hline \multicolumn{7}{|l|}{ Demographics factors } \\
\hline age (years) & -0.072 & 0.165 & -0.106 & 0.062 & -0.032 & 0.532 \\
\hline sex $($ male $=0$, female $=1)$ & -0.213 & 0.865 & 1.559 & 0.207 & 0.715 & 0.513 \\
\hline \multicolumn{7}{|l|}{ Disease factors } \\
\hline duration of disease & & & 0.043 & 0.409 & -0.019 & 0.694 \\
\hline length of use of biologics & & & -0.210 & 0.194 & -0.082 & 0.564 \\
\hline PASI score & & & 0.436 & $0.000^{*}$ & 0.252 & $0.021^{*}$ \\
\hline BMI & & & 0.299 & $0.018^{*}$ & 0.198 & 0.077 \\
\hline \multicolumn{7}{|l|}{ Psychological factors } \\
\hline anxiety (GAD-7) & & & & & 0.122 & 0.291 \\
\hline illness perception (PIBQ) & & & & & 2,209 & $0,000^{*}$ \\
\hline Adjusted $\mathrm{R}^{2}$ & \multicolumn{2}{|c|}{0.017} & \multicolumn{2}{|c|}{0.147} & \multicolumn{2}{|c|}{0.344} \\
\hline
\end{tabular}


Stigmatization is a frequent and serious phenomenon in patients with skin problems (Dimitrov et al., 2019), and it plays a significant role in the perception of quality of life. Research results have shown that it is important take into account not only the severity of skin symptoms (PASI), but also the localization of psoriatic lesions. In patients with generalized form and in patients whose psoriatic focus is located in visible places, we found a significantly lower quality of life which is in line with other studies (Daudén et al., 2013; Łakuta et al., 2018; Petraškiene et al., 2016). Łakuta and Przybyla-Basista (2017) have confirmed a significant relationship between the anatomical location of psoriatic lesions and experiences of stigmatization, negative emotional attitude towards the body, depression and social anxiety. Therefore, psoriasis can affect social interactions, mainly in patients who are going through a vulnerable period of social development.

Psoriasis and anxiety are chronic conditions and may exacerbate one another (Fleming et al., 2017). At the same time, anxiety determines the quality of life of psoriasis patients (Petraškiene et al., 2016). In the present study, Probable Generalized Anxiety Disorder (GAD-7 $\geq 10$ ) was identified in $26.5 \%$ of patients, and a severe level of anxiety (GAD-7 $\geq 15$ ) was found in $7.7 \%$ of patients. The prevalence of anxious symptomatology differs in various studies: $29.7 \%$ (HAD score) (Freire et al., 2011), 43\% (HAD score) (Richards et al., 2001), $13.1 \%$ (GAD-7 210 ) (Lamb et al., 2017). Variety of used tools, presence or absence of psoriatic arthritis, and treatment interventions are possible factors explaining the wide variation of the prevalence of anxiety in individual studies. In a study by Takahashi et al. (2014), anxiety and dysphoria significantly decreased after 16 weeks of biological treatment, suggesting a multi-dimensional effect of biological therapy - it positively affects skin appearance and the subjective symptoms of the disease such as pain and pruritus, alleviates patient anxiety and improves quality of life.

Although Pearson correlation shows association between anxiety and quality of life, anxiety in regression analysis is not a significant predictor of the quality of life. Kotsis et al. (2012) found in psoriatic arthritis patients that in addition to PASI or perception of disease symptoms, pain and also anxiety symptoms have a significant impact on quality of life. Pain associated with psoriatic arthritis (Coates and Halliwell, 2017) stimulates anxiety and may by a possible explanation for these differences. It was found that the intensity of pain or pain-related disability are events related with anxiety symptoms by patients with chronic pain (Costa et al., 2016).

In this study, the most important determinants of the quality of life in patients with psoriasis (undergoing biological therapy) are skin appearance (PASI) and in particular illness perception. Further studies have shown that illness perception (Salemi et al., 2016), consequences of psoriasis and illness concern (Fortune et al., 2002; Wahl et al., 2014) significantly determine the quality of life.

Despite the fact that the skin of the respondents is excellent (mean score of PASI was 3.00), 8.5\% of patients still have an extremely poor quality of life (DLQI $\geq 21$ ). This can be explained by how patients perceive and experience their disease - i.e. how they experience disease symptoms, and how much they are concerned about the development and consequences of the disease. Concerns, patients' fear of the consequences or complications of the disease, and relapse of skin symptoms are therefore very important predictors of quality of life. Illness perception, its cognitive and emotional processing and presentation of the disease to patients themselves are areas that need to be taken into account when trying to improve the quality of life of patients with psoriasis.

\section{Limitations of the study}

With regard to the design of the study (cross-sectional) it is not possible to deduce causal relationships between the observed phenomena. At the same time, data collection was performed in only one centre for biological treatment in the Slovak Republic, which could affect study results.

\section{Conclusions}

Quality of life is a complex phenomenon that is influenced by a wide range of factors. Research results have shown a link between disease severity, biologic treatment and quality of life. They have shown that the quality of life of psoriasis patients is determined by the extent of skin changes and, in particular, by the illness perception. By improving skin appearance through biologic therapy, it is possible to positively influence patients' perception of the disease and their quality of life. Therefore, it is very important to take into account the psychosocial aspects of the disease and to proactively identify high-risk patients. Subsequently, we recommend integrating more psychological help and support for these patients in clinical practice. Improving the health-related quality of life therefore requires a multidisciplinary approach in the care of patients with psoriasis.

\section{Conflict of interests}

The authors have no conflict of interests to declare.

\section{Authors'statement}

The authors confirm that the article is original, has not been submitted for publication in other journals, and has not yet been published either wholly or in part. They state that they are responsible for the research which they have designed and carried out; and that they have participated in drafting and revising the submitted manuscript - the content of which they have approved.

They also confirm that the research reported in the paper was undertaken in compliance with the Helsinki Declaration, and the study was approved by the ethics committee. The authors certify that there is no conflict of interest with any financial organization regarding the material discussed in the manuscript. 


\section{Determinanty kvality života pacientov so psoriázou na biologickej liečbe}

\section{Súhrn}

Ciel: Ciel'om štúdie bolo posúdit' kvalitu života pacientov so psoriázou liečených biologikami a analyzovat' viacero faktorov, ktoré ju môže ovplyvnit'.

Metódy: Realizovali sme prierezovú štúdiu u 117 pacientov liečených v Centre pre biologickú liečbu na Slovensku. Kanalyzovaným faktorom patrilo: kvalita života (Dermatology Life Quality Index - DLQI), vnímanie ochorenia (The Brief Illness Perception Questionnaire - BIPQ), úzkost' (General Anxiety Disorder-7 - GAD-7), závažnost' kožných zmien (Psoriasis Area Severity Index - PASI), lokalizácia kožných zmien, trvanie ochorenia, dížka užívania biologík, BMI.

Výsledky: Priemerné skóre DLQI bolo 9,03 (SD = 6,59, rozmedzie $=2-23)$. DLQI signifikantne korelovalo s hodnotou PASI $(r=0,347)$, dížkou užívania biologík $(r=-0,286)$, vnímaním ochorenia $(r=0,557)$ a úzkost́ou $(r=0,338)$. Hierarchická regresná analýza preukázala, že PASI $(\beta=0,252)$ a vnímanie ochorenia $(\beta=2,209)$ boli signifikantné prediktory kvality života pacientov. Záver: Výsledky štúdie naznačujú, že kvalita života pacientov so psoriázou liečených biologikami je determinovaná závažnostou ochorenia a vnímaním ochorenia. Z uvedeného dôvodu je vel'mi významné zahrnút psycho-sociálnu dimenziu (posúdenie, efektívne intervencie) do starostlivosti o túto skupinu pacientov.

Kl'účové slová: kvalita života; Psoriasis vulgaris; úzkost'; vnímanie ochorenia; závažnosṫ ochorenia

\section{References}

1. Ali FM, Cueva AC, Vyas J, Atwan AA, Salek MS, Finlay AY, et al. (2017). A systematic review of the use of quality-of-life Instruments in randomized controlled trials for psoriasis. $\mathrm{Br}$ J Dermatol 176(3): 577-593. DOI: 10.1111/bjd.14788.

2. Broadbent E, Petrie KJ, Main J, Weinman J (2006). The brief illness perception questionnaire. J Psychosom Res 60(6): 631-637. DOI: 10.1016/j.jpsychores.2005.10.020.

3. Broadbent E, Wilkes C, Koschwanez H, Weinman J, Norton S, Petrie KJ (2015). A systematic review and meta-analysis of the Brief Illness Perception Questionnaire. Psychol Health 30(11): 1361-1385. DOI: 10.1080/08870446.2015.1070851.

4. Calara PS, Norlin JM, Althin R, Carlsson KS, Schmitt-Egenolf M (2016). Health care Provider Type and Switch to Biologics in Psoriasis: Evidence from Real-World Practice. Bio Drugs 30(2): 145-151. DOI: 10.1007/s40259-016-0163-8.

5. Coates LC, Helliwell PS (2017). Psoriatic arthritis: state of the art review. Clin Med (Lond) 17(1): 65-70. DOI: 10.7861/ clinmedicine.17-1-65.

6. Costa ECV, Vale S, Sobral M, Graça Pereira M (2016). Illness perceptions are the main predictors of depression and anxiety symptoms in patients with chronic pain. Psychol Health Med 21(4): 483-495. DOI: 10.1080/13548506.2015.1109673.

7. Daudén E, Herrera E, Puig L, Sánchez-Carazo JL, Toribio J, Perulero N (2013). Impact of active and stable psoriasis on health-related quality of life: The PSO-LIFE study. Actas Dermosifiliogr 104(8): 685-693. DOI: 10.1016/j. adengl.2013.02.008.

8. Dimitrov D, Matusiak Ł, Szepietowski JC (2019). Stigmatization in Arabic psoriatic patients in the United Arab Emirates a cross sectional study.PostepyDermatolAlergol36(4): 425-430. DOI: 10.5114/ada.2018.80271.

9. Ferreira BI, Abreu JL, Reis JP, Figueiredo AM (2016). Psoriasis and Associated Psychiatric Disorders. A systematic Review on Etiopathogenesis and Clinical Correlation. J Clin Aesthet Dermatol 9(6): 36-43.

10. Finlay AY, Khan GK (1994). Dermatology Life Quality Index (DLQI) - A simple practical measure for routine clinical use. Clin Exp Dermatol 19(3): 210-216. DOI: 10.1111/j.1365-2230.1994. tb01167.x.

11. Fleming P, Bai JW, Pratt M, Sibbald C, Lynde C, Gulliver WP (2017). The prevalence of anxiety in patients with psoriasis: a systematic review of observational studies and clinical trials. J Eur Acad Dermatol Venereol 31(5): 798-807. DOI: 10.1111/ jdv.13891.

12. Fortune DG, Richards HL, Griffiths CE, Main CJ (2002). Psychological stress, distress and disability in patients with psoriasis: Consensus and variation in the contribution of illness perceptions, coping and alexithymia. Br J Clin Psychol 41(Pt 2): 157-174. DOI: 10.1348/014466502163949.

13. Freire M, Rodríguez J, Möller I, Valcárcel A, Tornero C, Díaz G, et al. (2011). Prevalence of symptoms of anxiety and depression in patients with psoriatic arthritis attending rheumatology clinics. Reumatol Clin 7(1): 20-26. DOI: 10.1016/j. reuma.2010.03.003.

14. Hagger MS, Orbell S (2003). A meta-analytic review of the common-sense model of illness representations. Psychol Health 18(2): 141-184. DOI: 10.1080/088704403100081321.

15. Higgins E (2017). Psoriasis. Medicine 45(6): 368-378. DOI: 10.1016/j.mpmed.2017.03.010.

16. Kaaz K, Szepietowski JC, Matusiak L (2019). Sleep quality among adult patients with chronic dermatoses. Adv Dermatol Allergol 36(6): 659-666. DOI: 10.5114/ada.2019.84007.

17. Kotsis K, Voulgari PV, Tsifetaki N, Drosos AA, Carvalho AF, Hyphantis T (2014). Illness perceptions and psychological distress associated with physical health-related quality of life in primary Sjögren's syndrome compared to systemic lupus erythematosus and rheumatoid arthritis. Rheumatol Int 34(12): 1671-1681. DOI: 10.1007/s00296-014-3008-0.

18. Kotsis K, Voulgari PV, Tsifetaki N, Machado MO, Calvalho AF, Creed F, et al. (2012). Anxiety and depressive symptoms and illness perceptions in psoriatic arthritis and associations with physical health-related quality of life. Arthritis Care Res (Hoboken) 64(10): 1593-1601. DOI: 10.1002/acr.21725.

19. Eakuta P, Przybyla-Basista H (2017). Toward a better understanding of social anxiety and depression in psoriasis patients: The role of determinants, mediators, and moderators. J Psychosom Res. 94: 32-38. DOI: 10.1016/j. jpsychores.2017.01.007.

20. Łakuta P, Marcinkiewicz K, Bergler-Czop B, BrzezińskaWcisło L, Słomian A (2018). Associations between site of skin lesions and depression, social anxiety, body-related emotions and feelings of stigmatization in psoriasis patients. Postepy Dermatol Alergol 35(1): 60-66. DOI: 10.5114/pdia.2016. 62287.

21. Lamb RC, Matcham F, Turner MA, Rayner L, Simpson A, Hotopf M, et al. (2017). Screening for anxiety and depression in people with psoriasis: a cross-sectional study in a tertiary referral setting. Br J Dermatol 176(4): 1028-1034. DOI: $10.1111 /$ bjd.14833.

22. Leventhal H, Diefenbach M, Leventhal EA (1992). Illness cognition: Using common sense to understand treatment adherence and affect cognition interactions. Cognitive Therapy and Research 16(2): 143-163. DOI: 10.1007/BF01173486.

23. Mattei PL, Corey KC, Kimball AB (2014). Psoriasis Area Severity Index (PASI) and the Dermatology Life Quality Index (DLQI): the correlation between disease severity and psychological 
burden in patients treated with biological therapies. J Eur Acad Dermatol Venereol 28(3): 333-337. DOI: 10.1111/jdv.12106.

24. Menting SP, Sitaram AS, Bonnerjee-van der Stok HM, de Rie MA, Hooft L, Spuls PI (2014). Drug survival is not significantly different between biologics in patients with Psoriasis vulgaris: a single-centre database analysis. $\mathrm{Br} \mathrm{J}$ Dermatol 171(4): 875-883. DOI: 10.1111/bjd.13001.

25. Norris D, Photiou L, Tacey M, Dolianitis C, Varigos G, Foley P, et al. (2017). Biologics and dermatology life quality index (DLQI) in the Australasian psoriasis population. J Dermatolog Treat 28(8): 731-736. DOI: 10.1080/09546634.2017.1329501.

26. Obradors M, Blanch C, Comellas M, Figueras M, Lizan L (2016). Health-related quality of life in patients with psoriasis: a systematic review of the European literature. Qual Life Res 25(11): 2739-2754. DOI: 10.1007/s11136-016-1321-7.

27. Parisi R, Symmons DP, Griffiths CE, Ashcroft DM (2013). Global Epidemiology of Psoriasis: A Systematic Review of Incidence and Prevalence. J Invest Dermatol 133(2): 377-385. DOI: 10.1038/jid.2012.339.

28. Petraškiene R, Valiukevičiene $S$, Macijauskiene J (2016). Associations of the quality of life and psychoemotional state with sociodemographic factors in patients with psoriasis. Medicina (Kaunas) 52(4): 238-243. DOI: 10.1016/j. medici.2016.07.001.

29. Puig L, Thom H, Mollon P, Tian H, Ramakrishma GS (2017). Clear or almost clear skin improves the quality of life in patients with moderate-to-severe psoriasis: a systematic review and meta-analysis. J Eur Acad Dermatol Venereol 31(2): 213-220. DOI: $10.1111 / j d v .14007$.

30. Reich K, Griffiths CE (2008). The relationship between quality of life and skin clearance in moderate-to-severe psoriasis: lessons learnt from clinical trials with infliximab. Arch Dermatol Res 300(10): 537-544. DOI: 10.1007/s00403-008-0885-7.
31. Richards HL, Fortune DG, Griffiths CE, Main CJ (2001). The contribution of perceptions of stigmatisation to disability in patients with psoriasis. J Psychosom Res 50(1): 11-15. DOI: 10.1016/s0022-3999(00)00210-5.

32. Salemi S, Ghasemi A, Arefi M (2016). The relationship between illness perception, depression and quality of life in patients with psoriasis who referred to Haj Daie dermatology clinic in Kermanshah. Der Pharmacia Lettre 8(3): 85-89.

33. Spitzer RL, Kroenke K, Williams JB, Löwe B (2006). Brief Measure for Assessing Generalized Anxiety Disorder. The GAD-7. Arch Intern Med 166(10):1092-1097. DOI: 10.1001/ archinte.166.10.1092.

34. Takahashi H, Iinuma S, Tsuji H, Honma M, Iizuka H (2014). Biologics are more potent than other treatment modalities for improvement of quality of life in psoriasis patients. J Dermatol 41(8): 686-689. DOI: 10.1111/1346-8138.12544.

35. Wahl AK, Robinson HS, Langeland E, Larsen MH, Krogstad AL, Moum T (2014). Clinical characteristics associated with illness perception in psoriasis. Acta Derm Venereol 94(3): 271-275. DOI: 10.2340/00015555-1673.

36. World Health Organization (2016). Global report on Psoriasis, $48 \mathrm{p}$.

37. Wu CY, Chang YT, Juan CK, Shen JL, Lin YP, Shieh JJ, et al. (2016). Depression and Insomnia in Patients with Psoriasis and Psoriatic Arthritis Taking Tumor Necrosis Factor Antagonists. Medicine (Baltimore) 95(22): e3816. DOI: 10.1097/ MD.0000000000003816

38. Zhang $\mathrm{M}$, Hong L, Zhang T, Lin $\mathrm{Y}$, Zheng S, Zhou X, et al. (2016). Illness perceptions and stress: mediators between disease severity and psychological well-being and quality of life among patients with Crohn's disease. Patient Prefer Adherence 10: 2387-2396. DOI: 10.2147/PPA.S118413. 